\title{
BRAZILIAN FOREIGN POLICY IN HEALTH DURING DILMA ROUSSEFF'S ADMINISTRATION (2011-2014)
}

Eduardo Gómez

Senior Lecturer in International Development at King's College London

International Development Institute, London, Inglaterra.

Email<eduardo.gomez@kcl.ac.uk>

Fernanda Aguilar Perez

Joint PhD Candidate from University of São Paulo,

King's College London, with a Fapesp/Capes Scholarship, from São Paulo Research Foundation.

São Paulo, SP. Brasil.Email<fernanda.aguilar_perez@kcl.ac.uk

http://dx.doi.org/10.1590/ 0102-6445171-197/98

For the past 20 years, public health has become a central feature of Brazilian international relations and foreign diplomacy, particularly under Luiz Inácio Lula da Silva's (2003-2010) administration ${ }^{1}$. During such period, the emphasis on humanitarian matters, social inclusion, justice, and antipoverty, when combined with commitment to multilateralism in the international sphere, motivated his administration's approach to the Brazilian Foreign Policy (henceforth, BFP) in health (Cervo, 2010; Hermann, 2011; Leite, 2011; Ventura, 2013). BFP in health played an important - and widely acclaimed - role in Brazil's SouthSouth cooperation, alongside agriculture and education (Hirst, 2012, p. 11). In the course of time, Lula's international activities drew considerable international attention and praise; and health was considered a topic that could increase the Brazilian participation in international relations (Ventura, 2013).

\footnotetext{
1 This article further debates the work introduced by Ventura and Perez (2015).
} 
During Lula's term, the country showed the protagonism of the BPF efforts by supporting regional agendas, which emphasized health in the scope of the Community of Portuguese Speaking Countries (CPLP) and the Union of South American Countries (USAN, Unión de Naciones Suramericanas - Unasur) - a regional organization comprised of a Health Council and an Institute of Government in Health -, as well as other important international policy initiatives (Buss and Ferreira, 2011; Ventura, 2013).

In this article, we question the extent to which the BFP in health continued during President Dilma Rousseff's first term administration (2011-2014). In contrast to what was seen under Lula's government, the BFP in health in the 2011-2014 period has faced a decline in its financial, organizational, and international assistance endeavors. While some scholars have recently characterized Lula's BFP efforts as "autonomy by diversification" or "reciprocal multilater172 alism” (Vigevani and Cepaluni, 2007; Cervo, 2010), others have described Dilma's administration as a "systemic decline", with a corresponding lack of commitment to sustaining Lula's BFP efforts (Cervo and Lessa, 2014).

We attribute these outcomes to the following factors: firstly, there was a decline in the presidential and congressional budgetary support for the Ministry of Foreign Affairs (MOFA); secondly, Dilma's inward focus and commitment to national economic and social welfare development, which, in turn, has created a lack of interest in BFP and has discovered its association with national development. This change of focus has also resulted in an increased separation between the Executive Office of the President and the MOFA, with a corresponding decrease in diplomatic motivation and commitment to the BFP in health. Thirdly, the lack of interest during Dilma's administration in BFP has created little involvement in unifying the state and civil society (including private sector actors) to work together at international level. 


\section{Methodology}

A single case-study research was conducted and found empirical data from several sources. Brazil was selected because the authors focused on understanding Brazil's evolutionary change in the BFP in health.

With respect to qualitative data for this study, firstly, the authors randomly distributed survey questionnaires by email to several Brazilian diplomats working within the current Dilma's administration, in diplomatic posts in Brazil and abroad. The questions were emailed on February 2016 with an Informed Consent Form, and ten surveys were answered after a month. The questionnaires had four open-ended questions ${ }^{2}$ and the answers were emailed as well. The results were used to support assertions made about the three aforementioned factors, contributing to a downward shift in the BFP in health. Secondly, the theoretical literature and empirical case study examples discussed in this study drew from several primary and secondary peer-revised scholarly articles and policy reports. Finally, empirical budgetary data illustrating congressional commitments to the BFP in health were obtained by revising the Brazilian Official Federal Budget.

In this paper, foreign policy is understood as a public policy, therefore defined as the state and government in action at international level (Pinheiro and Milani, 2012). Only preexisting programs or projects being negotiated during Lula's administration were considered for this analysis.

2 The questions were: (1) Was there an abrupt change in the BFP during Dilma Rousseff's first term (2011-2014) when compared to Luiz Inácio Lula da Silva's era (2003-2010)? If so, what are the reasons for this change in your opinion? If not, what continued to be the same, in your opinion?; (2) Do you believe that Dilma's foreign policy has got a main idea/concept for the BFP in the considered period of time?; (3) Cervo and Lessa (2014) use the word "decline" as a descriptor of the BFP under Dilma's era. Would this word be the best one to describe the changes that took place during Dilma's first term?; (4) Are there differences in working with Itamaraty between Lula's and Dilma's era that can be highlighted? 


\section{Foreign policy in health rise and changes}

In recent years, a considerable amount of scholarly literature has been aimed on the reasons for, and the strategies behind, government's interest in and commitment to bilateral and multilateral foreign policy in health. Analyses of this interest and commitment are recent in the global health diplomacy literature, and this work focused on the various political, civil society, and normative commitments behind governments interested in providing funding and technical assistance to other nations in the area of healthcare (Michaud and Kates, 2013; Novotny, Kickbusch and Told, 2013; Kickbusch et al., 2013; Lee and Smith, 2011; Labonte and Gagnon, 2010). Two major schools of thought dominated the literature's discussion on the rationale and on the evolution of this kind of foreign aid.

One school of thought emphasizes the soft-power strategies behind a government's provision of foreign aid in health.

174 This is developed based on Joseph Nye's discussion about soft power (Nye, 2004), which focuses on state strategies to increase its international political influence through the demonstration of success in the domestic policy as well as culture, in turn persuading other states that their policy approach to particular issues is more effective - in a sense, "leading through example”. Soft-power strategies in health have aimed on the state's interest and ability to influence international discourse and policy actions showing domestic success in health policy and outcomes, as well as a successful compliance with international normative commitments in health. According to such literature, states engage in providing foreign aid in health to bolster their ability to shape the international policy agenda in health, persuading other nations that, based on their success at the domestic level, their particular approach to public health is effective and should be emulated by other nations (Lee and Gómez, 2011; Thompson, 2005). Some people claim this reveals a government's successful and emerging 
power status (Twigg, 2012; Bliss, 2011; Lee and Gómez, 2011; Thompson, 2005). In addition to foreign aid in health, these states also bolster their international policy and political influence by proactively engaging in diplomatic exercises and marketing strategies. These would reveal their success in tackling pressing healthcare challenges and inequalities within their borders (Gómez, 2012; Lee and Gómez, 2011), and in turn establish themselves as experienced and well-capable states that are committed to eradicating a disease. Such act provides legitimacy and influence when seeking to shape international health policy discussions. These states often achieve this process by using international institutional forums, such as conferences and task force meetings within multilateral governing bodies, like the United Nations (UN) and the World Health Organization (WHO), to discuss their success in meeting healthcare needs, achieving humanitarian objectives and saving lives (Watt, Gómez and McKee, 2013).

Nations may also have international reputational concerns and aspirations for providing foreign aid in health. Often, interest in international reputation building and rejuvenating a state's image in the international sphere motivates government officials to provide assistance (Chan, Chen and $\mathrm{Xu}, 2010$; Huang, 2010). This occurs when states have acquired a reputation as a hostile state towards other nations, either through unfavorable trade relations, national security threats, or military action. The goal in this scenario is to use bilateral and/or multilateral assistance to rejuvenate the government's international reputation as a peaceful and benevolent state (Michaud and Kates, 2012; Feldman and Michaud, 2010). As Feldman and Michaud (2010) maintain, for example, shortly after the invasion of the United States to Iraq in 2003, to rejuvenate the reputation of Bush's administration as a benevolent, caring actor, the US Navy was delegated the task of providing medical assistance to local Iraqi communities. 
Finally, others claim that states engage in foreign aid in health and increase their international assistance over time in order to gain access to foreign markets. A work by Huang (2011), for example, shows how China's efforts to provide bilateral aid to several African nations was a strategic way to enter domestic African markets. Huang (2011) found that China's export of pharmaceutical drugs, though appearing as an altruistic move on the surface, eventually revealed the country's intention of importing its cheaper drug products into Africa and establishing a market for China's pharmaceutical medicine. Moreover, it was subsequently revealed that the quality of medicine and treatment provided for China's medical assistance to selected African communities was low, suggesting that the main motive was to establish friends and gain access to markets, not necessarily benevolent (Huang, 2011). Similar medical aid in exchange for economic and natural resources, such as access to cheaper

176 barrels of oil, was found in Cuba's medical primary healthcare work in Venezuela (Werlau, 2013). One could extend this to argue that Cuba's recent presence in Brazil has partly been motivated by the Cuban state's efforts to earn money through our country's payment for medical assistance (Cowley, 2014).

While the global health diplomacy literature has certainly contributed to our understanding of the reasons why foreign aid in health is provided, it does not speak to the reasons why governments gradually change their foreign policy strategies in health. Why, for instance, do presidents and governing political parties suddenly change their views and interest in providing foreign aid in health, leading to either a decline or a complete cessation in such assistance? Also puzzling is when this shift in foreign policy focus occurs on similar types of governing political parties, or the same one, that has been committed to providing foreign aid in health as a normative and ethical extension of their pre- 
existing domestic commitment to poverty eradication and universal healthcare provision. In this political context, we should expect that governing political parties providing foreign aid in health, guided by these normative beliefs, might not try to dramatically change their foreign assistance strategies. For this could be viewed as a breach of commitment to preexisting political party tenants, could threaten domestic electoral support, and even the government's broader credibility at international level.

The case of Brazil in this article nevertheless builds on the existing global health diplomacy literature by showing that governing political parties and presidents may eventually decide to decrease their foreign policy activities in health. Moreover, this may occur even when incumbent presidents and political parties adhere to normative tenants adopted by previous administrations, safeguarded by their governing political party. We argue this occurs when there is a decrease in federal budgetary support for federal agencies, a corresponding change in the financial managerial autonomy and control, as well as the president's inward focus on national development in lieu of foreign policy in health - or in general.

\section{Possible reasons for Dilma Rousseff's different approach to the Brazilian Foreign Policy}

In Brazil, the government's provision of healthcare assistance, by way of policy and technical assistance, reflects one small, yet historically large, aspect of its foreign policy activities. During the investigation period, that is, Dilma's first term in office (2011-2014), the government's change on the BFP in health reflected a broader shift in the government's foreign policy activities.

To understand Dilma's administration change in the BFP strategies in health, the authors sent a questionnaire to diplomats, aiming at discovering reasons and motiva- 
tions for the decline of Dilma's administration on the BFP in health, an outcome that was corroborated by the recent work of Cervo and Lessa (2014).

According to our survey's participants, the first reason accounting for why BFP in health has declined during Dilma's term has to do with her lack of personal interest in international affairs, choosing instead to focus on national development. Dilma and her close advisors have not been as interested in foreign policy matters as Lula's administration. This is mainly due to the fact that Dilma has been more concerned with national economic and social development, and therefore has an inward, rather than global, focus. Therefore, she has been unable to understand the role of foreign policy as a capable tool to boost domestic social and economic development.

The use of foreign policy as a mechanism for national development is a long-existing tradition in the BFP, and in 178 the 20th century, domestic development became a fundamental issue to Brazilian foreign affairs (Lafer, 2000). Nonetheless, President Dilma does not believe that diplomacy is able to turn international contexts into national opportunities for growth. This is surprising given the fact that she hails from the same political party as former President Lula, that is, the Workers' Party (PT, acronym in Portuguese). Because of this, she has essentially adopted the same ideological principles and moral components of Lula and the PT, as ending poverty and a commitment to end hunger.

According to diplomats in our survey, the second reason for the decline in the BFP during Dilma's term was the budget cuts faced by the MOFA. The main ideas and principles of the foreign policy remain, as well as the general goals. For instance, BRICS (Brazil, Russia, India, China and South Africa) partnerships and good relationships with South American nations are still crucial to Brazil. What has nevertheless changed in recent years are the financial 
resources available for these activities, and the management of such resources.

The interviewed subjects indicted that such decline in federal funding has affected Brazilian diplomacy in a very specific way: foreign affairs diplomats are no longer able to travel for meetings or negotiations abroad. To save money, the MOFA, aka Itamaraty, has been sending diplomatic officials within countries to specific negotiations, rather than sending diplomats from Brazil that know the issues better and are therefore better equipped to engage in negotiations; this, in turn, has hindered the government's international reputation in diplomatic relations. The participation of experienced and knowledgeable diplomats is important because they are responsible for increasing and positively influencing Brazil's participation in politics debates and decisions.

Cooperation projects were greatly impacted too, since the Brazilian Cooperation Agency (BCA) has lost a great deal of its budget. Consequently, Dilma's administration was unable to commit to new international cooperation projects. Hence, the participants noted that the BCA has tried to explore ways for engaging in different tasks without acquiring and earmarking more funding.

In addition to a decline in funding, during Dilma's first term in office, Itamaraty partially lost its autonomy in the budgetary management. The government's contributions to international organizations, such as the CPLP, now falls under the responsibility of the Ministry of Planning, Budget, and Management. This loss of financial autonomy and overall reduction in the budgetary support has greatly impacted Itamaraty's daily operations. Even activities that did not suffer presidential interference, such as the consular services, were affected.

Thus, with a decrease of Itamaraty's funding and a lack of presidential support and attention, Itamaraty's diplomats have not been motivated to conduct their work. Based on 
our survey respondents, such professionals may not understand the point of spending hours negotiating Brazil's interests in international forums if the president and other government officials will not value their efforts.

As a further consequence to this situation, the survey respondents maintain that there has been a sense of "separation" between Dilma's administration and Itamaraty. The president and her advisors do not understand the importance of Itamaraty's work and how it affects national development. At the same time, due to this indifference and apathy of Dilma's administration towards them, Itamaraty diplomats are unable to understand what she wants and expects from them and how to demonstrate their relevance and importance to the country.

These findings support scholars, emphasizing the importance of presidential leadership in foreign policy. For example, Hudson (2014) claims there are many variables that 180 must be taken into consideration when analyzing the influence of a country's leader in foreign policy, such as the type of political regime, whether or not the leader is interested in foreign policy, the domestic situation, and the ability of leaders' advisors to read different contexts. Brazil has a strong presidential system, although fragmentation of parties and need of forming coalitions impact on presidential rule (Mainwaring, 1997; Figueiredo and Limongi, 2000). During Dilma's first term, as mentioned, the economic situation was still fairly stable. With a whole office that is not deeply concerned with international affairs and a leader that does not recognize the BFP's potential role, Itamaraty was relegated to a distant relationship.

Finally, yet another reason for the decline in BFP under Dilma's term is related to her administration's inability of establishing a clear set of ideas for foreign diplomatic engagement. Based on the respondents to our questionnaires, who built their opinion on a previous point empha- 
sized by Cervo and Lessa (2014), Dilma's administration has no clear idea on how they could bring the government and civil society together to work on foreign policy. Some diplomatic officials suggested that there essentially was no foreign policy agenda under Dilma's term: she has no long-term perspective or vision for the country in the area of foreign policy. Rather, Dilma tends to value short-term, feasible, and visibly concrete results. International diplomacy, however, does not provide these kinds of short-term gains and expectations and is more likely to produce more subtle outcomes. In this situation, the nonexistence of a foreign policy agenda is problematic. In the best scenario, Brazil would neither advance nor come up with new projects nor would it retreat. However, this immobility is leading the country to lose opportunities to new foreign policy ideas and/or those positions Brazil had already acquired.

The last idea from the questionnaires was the perception that Itamaraty had problems of its own. The MOFA also showed difficulties recognizing what Dilma wanted from it, which could be a consequence of choice taken by the Ministers of Foreign Affairs in the period. They both suffered from a lack of political ability to deal with the demands of the Esplanade of Ministries. The First Minister, during Dilma's first administration, Antônio Patriota (2011-2013), was a brilliant diplomat with no skills to deal with the Brazilian congress. Luiz Alberto Figueiredo (2013-2015) was the second Minister when Itamaraty lost its course of action. None of them was able to develop the same relationship with political representatives as Amorim, a minister considered a clever interlocutor who has a close bond with former president Lula.

Furthermore, in recent years, Brazil has become more reactive than proactive in its diplomatic activities. Snowden's scandal, as well as the impeachment of President Fernando Lugo in Paraguay and the Rio+20 Conference, essentially forced Brazil, as a regional leader, to react. Dilma is more 
likely to pay attention to bigger events or to activities with significant and tangible international implications. Consequently, Brazil has lost to a certain extent its international credibility and prestige in foreign affairs.

\section{Brazilian Foreign Policy and health}

The analysis of the actors and projects here identified suggest two ongoing processes taking place in the BFP in health: one in which the budget cuts or the BFP problems resulted in worse outcomes for health projects, and another, in which changes can be noticed, however the causality is yet unclear. Those are the cases of BRICS and Unasur, in which there has been a decline but bureaucratic inertia has avoided worse consequences to the outcomes of health matters.

Discontinuities and problems are clear in the cases of Oswaldo Cruz Foundation - Fiocruz (part of the Brazilian Ministry of Health) and the BCA (part of Itamaraty). The

182 Ministry of Health, for example, acquired considerable participation in the country's health-related international actions during Lula's administration, and Fiocruz saw them increasing greatly during Lula's two terms. This was part of a process Brazil underwent, which was defined by BFP experts as "foreign policy horizontalization": several government agencies, not only the MOFA, were responsible for foreign policy decision-making. Former Minister of Health, José Gomes Temporão, stated in an interview that during his years in office (2007-2010), he engaged in international activities every "two months directly with Celso Amorim (Minister of Foreign Affairs under Lula)," who worked with him a Brazilian global health agenda (Temporão, 2014). Approximately $60 \%$ of all the departments in the Ministry of Health $(\mathrm{MOH})$ were involved in international affairs (Badin and França, 2010).

In 1998, the MOH established the Office of Health International Affairs (AISA, acronym in Portuguese), 
which is the main agency of the $\mathrm{MOH}$ working on foreign health policy. Due to its extensive experience in international negotiations, the $\mathrm{MOH}$ delegated new tasks to the AISA: they signed with the Pan American Health Organization (PAHO) a 10-year-long Cooperation Agreement (2009-2019), so that the office could contribute to projects involving Unasur, the Caribbean, CPLP, and African countries. PAHO emphasizes, in a report, this Agreement is still under execution, and its main goal is to strengthen AISA "in consonance with national health strategies and the BFP" (PAHO, 2014, p. 205). Until the first semester of 2014, the MOH had received US $\$ 12.644 .999,21$ to accomplish this task (PAHO, 2014, p. 218). However, in recent years, the $\mathrm{MOH}$ has been trying to increase the management of foreign policy projects, and AISA did not innovate its action or programs concerning BFP.

Several changes took place in Fiocruz, a division of the $\mathrm{MOH}$ that focuses on research, education, and technical cooperation. While Fiocruz did not observe a decline in research funding, the absence of available data for international cooperation suggests funding problems for these activities since 2008 (Senado Federal, 2003-2014). However, the reports of Fiocruz official activities for the period of 2011-2014 mention that most international activities were continued or consolidated (Fiocruz, 2013, 2014, 2015).

One of the main Brazilian projects in health under the responsibility of Fiocruz was the establishment of a Mozambican laboratory for the production of antiretroviral medicine. With an investment of $\mathrm{R} \$ 40$ million for the period of 2008-2014, the Mozambican Medicines Society (Sociedade Moçambicana de Medicamentos - SMM) would be the first $100 \%$ public laboratory in Africa and an example of what a structuring cooperation in health would really mean (Ventura, 2013). The project, as stated by Amorim (2013, p. 148), came at the request of the Mozambican gov- 
ernment, and the cooperation agreement for the establishment of such industry was signed by the two countries in 2003, during the first of three visits that Lula would make to the African country (MOFA, 2011; Ventura, 2013; Milani and Lopes, 2014).

In November 2012, the first locally produced antiretroviral was delivered to the Mozambican MOH (Fiocruz, 2013a), however many problems happened along the way, from plant's building to managerial issues (Milani and Lopes, 2014). President Lula was personally committed and took the lead when problems emerged, acquiring financial support from the Brazilian company "Vale" to ensure the construction of the plant, at the same time visiting Mozambique to "speed up the understandings" (Milani and Lopes, 2014, p. 71). Lula returned to the country, now as a former president, to personally follow the delivery of the first batch of drugs. Dilma had officially visited Mozambique in

1842011 to hold meetings with local investors - highlighting then the exploration of mineral coal, investments in energy, ports, and airports infrastructure etc. and from the Brazilian Development Bank (BNDES, acronym in Portuguese) (Presidential Office, 2011; Milani and Lopes, 2014).

In July 2012, the Brazilian government wanted to take advantage of Dilma's presence in Mozambique for the IX Conference of Chiefs of State and Government of CPLP to officially open the industry. However, not only the Mozambican government did not want to inaugurate the factory, justifying this on the grounds that there had not been any production of medicine, but Dilma also did not go to Maputo to examine the situation; instead, Vice-President Michel Temer and the Minister of Foreign Affairs Patriota went in her place. Such fact implied she was not committed to the entire enterprise (MOFA, 2012; Milani and Lopes, 2014).

The Brazilian government was particularly worried when the Institute for Management of Companies and State Par- 
ticipation (IGEPE, acronym in Portuguese), a Mozambican government organ specialized in public-private partnerships, took control over the industry; there were even rumors about a possible privatization process to sell SMM (Milani and Lopes, 2014). Nevertheless, IGEPE had been in charge alongside the $\mathrm{MOH}$ from Mozambique for the implementation, oversight, and evaluation of the Cooperation Agreement since 2011. In the same year, not only the industry of medicines received the name of Mozambican Medicines Society, but IGEPE was declared to be the owner of SMM (but the Mozambican Ministry of Health still participates in the SMM administration by appointing the direction of its administrative council as well of its executive director) (Brasil and Moçambique, 2011; Russo et al., 2014).

According to Russo et al. (2014), Brazil was not completely aware of how complicated the implementation of a cooperation project in a country with different social, political, and historical background would be. While the Brazilian $\mathrm{MOH}$ is responsible for the production and surveillance of medicines sold within the country, in Mozambique, the $\mathrm{MOH}$ only supervises IGEPE's work and will only oversee the project's follow-up after 2017 - period when the Brazilian relationship with implementation efforts and training for the human resources for SMM is supposed to be finished in the African country.

Discontinuities and problems are much easier to understand when examining the case of the MOFA. It had significant cuts to its budget during Dilma's first term: even resources used directly by this Ministry for international cooperation, as described in the national budget, were reduced. In 2005, BRL 430.705.861 were implemented as international cooperation; in 2011, this amount was decreased to BRL 82.188.671 and, in 2012, to BRL 63.002.107. As seen, until 2008, the amount due to international cooperation was considerably higher (Brasil, 2013, 2015a; Senado Federal, 2015). 
Furthermore, if we consider the federal budget for the BCA, there was a noteworthy decrease of the available resources. While during Lula's years, the BCA had its budget revised and increased, in Dilma's, this trend was reversed. In 2010, the BCA had, for South-South Cooperation with Africa alone, US\$20 million available. Two years later, there was only US\$9.9 million available (Hirst, 2012; Abdenur et al., 2014).

The trilateral cooperation among Brazil - Japan - Angola illustrates the impact this budget cut. Since 2009, Brazil and Japan had been working together in a partnership that would become, in 2011, a trilateral cooperation project for strengthening the Angolan health system (BCA, 2015). Focused on the Primary Health Care and on the development of human resources of two Angolan hospitals, this project, known afterwards as 'Proforsa', implicated the Brazilian Agency of International Cooperation (ABC, acronym in Portuguese), Fiocruz, 186 the Universidade Estadual de Campinas, the Japanese International Cooperation Agency (JICA), and the Angolan Ministry of Health (MINSA) (Fiocruz, 2013c; BCA, 2015). Concluding in 2014, Proforsa was the most recognized cooperation project between Angola and Brazil; however, it suffered greatly on its third year of implementation due to the ABC budget cuts. The project only continued because JICA and MINSA paid for what $\mathrm{ABC}$ could no longer contribute to (Fonseca, Esteves and Gomes, 2015).

As mentioned, there were other agencies that saw their BFP activities gradually weaken, though these outcomes during Dilma's administration are difficult to measure. For instance, the CPLP and Unasur were both considered important agencies and examples of Brazil's international cooperation for health. A Strategic Plan for Cooperation in Health was developed under the scope of CPLP, and was supposed to last from 2009 to 2012. With a modest budget of 14 million Euros, the plan established seven strategic 
axes of action and emphasized the development of human resources for health in CPLP countries (Ventura, 2013).

In April 2013, a technical meeting to assess the Strategic Plan 2009 - 2012 took place in Lisbon, Portugal. The assessment report combines the implementation evaluation of the established goals and new ideas for upcoming projects. Such document emphasizes that only two projects had an "acceptable degree of implementation" (CPLP, 2013, p. 5): a project to boost networks of structuring institutions and the creation of a Centre of Specialized Medical Training in Cape Verde. It also states that some projects were not developed or were only partially developed, and that networks for malaria and HIV/Aids were not operational. Despite all problems, the Plan was considered important and will last until late 2016 (CPLP, 2013).

Additionally, the report states that governance tools of such Plan need to be improved because there are flaws in dialogue and leadership, as well as inadequate follow-up in the implementation of projects. The domestic political issues of countries changed national strategies and had negative consequences to the management and development of projects (CPLP, 2013).

From the year 2008 to 2009, Brazil decreased its contribution to CPLP; however, the MOFA was no longer responsible for these funds: the Ministry of Planning, Budget and Management became in charge of them (Senado Federal, 2003-2014). One question should be highlighted: Dilma's term started in 2011, and documents mark that this change happened in the middle of Lula's second term. Therefore, the decrease of MOFA's autonomy cannot be associated with Dilma's considerations for the BFP.

A negative shift in the BFP under Dilma's administration can be noticed in her government's work with other nations from BRICS. Brazil has been taking part in the BRICS Chiefs of State and Government Annual Summits 
since 2009, although the country's recent participation has become lackluster, leaving room for China and Russia's growing influence (Ventura, 2013; Cervo and Lessa, 2014). The BRICS' Ministers of Health Meetings started on July 2011. During a meeting that took place in Brasília, on December 2014, the Ministers demonstrated that the main emphasis of the group was still access to medicines and the fight against HIV/Aids, hepatitis C, tuberculosis and other illnesses that are public health threats to the nations from BRICS. In the recent IV Meeting of Ministers of Health for the BRICS, they also agreed to develop a cooperation plan to combat tuberculosis, with an emphasis on guaranteeing the share of technology and on providing tuberculosis drugs for all in need. The deadline for the development of an operational framework for this plan was the first semester of 2015 (BRICS, 2014).

Tuberculosis is an important issue for BRICS, since 188 it represents $50 \%$ of all cases of this disease in the world (BRICS Policy Center, 2014). However, the implementation of the projects has been running slowly: in the beginning of 2013, the world already knew that BRICS were debating how to combat more resistant types of tuberculosis, and that a plan of action was expected for 2014 (Fiocruz, 2013b). While recently the issue of tuberculosis was discussed with interest in a wider scope of action, there still seems to be within the group a protraction in the decision-making process, as well as in the development of future projects. The Brazilian Minister of Health, Arthur Chioro, said that the group would propose the creation of a fund to face the issue, but did not specify which responsibilities Brazil would take or how the country would participate (BRICS Policy Center, 2014). This suggests once again that Dilma's administration did not prioritize increasing Brazil's leadership role in this group.

Health is a key topic to the Unasur, and, in this case, Brazil's recent domestic constraints had a negative impact 
too. Health is considered a "funding pillar of the [South American] continent," and for the last five years, Unasur member-States have participated in the World Health Assembly (WHA) as Unasur (ISAGS, 2015a, p. 1). Besides developing ten common proposals about different topics to be presented at this WHA meeting (some of them concerning the post-2015 development agenda), and recalling the importance of the impact of quality of food intake to diseases like obesity and malnutrition at the 68th WHA, Unasur went further. In 2014, the Union got involved with the South-American and Arabian Countries Summit - ASPA Summit), introducing in April of that year the Lima Declaration. This was signed up by all ministers of health from all the implicated States, and it described common problems and pursue for health systems strengthening (Fiocruz, 2014; ISAGS, 2015b).

Likewise, Unasur had a meeting with the CPLP on May 2014. Both international organisms emphasize the strength of structuring networks and the knowledge propagation, thus they combined their efforts to develop a Joint Networking Department for the National Institutes of Health or Public Health, bringing together institutes from both geographic parts of the world (South America and Africa as RINS/Unasur and RINSP/CPLP). The goal of this network was to understand how inequities in health are socially determined, and to formulate a joint proposal to solve common problems (CPLP, 2014).

Most of Unasur efforts count on ISAGS (Instituto SulAmericano de Governo em Saúde, in Portuguese) support. However, although the Institute was created in 2011, it was only as recently as June 1st 2015 that the Brazilian Chamber of Deputies approved the document "Headquarters Agreement Between the Federative Republic of Brazil and the Union of South American Nations for the Establishment of the South American Institute of Government in Health." 
Worse still, this document still needs the approval of the Federal Senate, so that ISAGS becomes a regular institution in the country (Brasil, 2015b).

With respect to the recent efforts to reform the WHO, Brazil has nevertheless remained committed to its actions and involvement. For several years, the country has been pressing for several changes in multilateral institutions. As to the WHO, Brazil has been very critical for the lack of priority and attention paid to health and development in the official documents (Ventura, 2013). During international negotiations over the WHO's 2014 budget, Brazil agreed to increase its contribution to the WHO, claiming that it would also increase the pressure for a more open position from such institution to developing countries requests. Russia, India, and China also accepted to increase their contributions (Chade, 2013).

Unasur, with the support of Brazil, also asked for a wide reform at the WHO in 2012, highlighting that not only the 190 international organization financing should be revised, but also the emphasis given to social determinants of health (ISAGS, 2012). Even domestic organs, such as AISA, followed the negotiations and coordinated actions connected to the reform process (PAHO, 2014).

Regarding the WHO actions against Ebola and this disease outbreak, Brazil donated BRL 25 million to the UN, and of this amount, $50 \%$ were sent to the WHO, $26 \%$ to the UN High Commissioner for Refugees, $18 \%$ to the World Food Program, and 6\% to the UN Mission for Ebola Emergency Response (UNMEER) (MOFA and MOH, 2014). The country has also submitted what it understands as "kits", i.e. basic material needed for health care (as gloves) with medicines that would help 500 people for three months. They were sent to Guinea, Sierra Leone, Liberia, and the WHO (MOFA and MOH, 2014).

When compared to other BRICS nations, such as China, Brazil's efforts were weaker. China not only donated 
US\$ 32,540 million for humanitarian aid, but also sent US\$ 5 million in health care material and 115 specialists in communicable diseases to the most affected countries (Taylor, 2015). This comparison suggests that perhaps Brazil could have contributed more to the Ebola outbreak.

Light should be shed on Brazil's position regarding the debates about global health and security. In the UN security council sessions about Ebola crisis, Brazil emphasized that the emergency should be interpreted with a social point of view. Ambassador Guilherme Patriota's speech on the 7268th UN security council meeting claimed that Brazil welcomed the creation of the UN Mission for Ebola Emergency Response. However, the diplomat stressed that Brazil "underline[s] the need to treat the outbreak first and foremost as a health emergency and a social and development challenge rather than a threat to peace and security" (UNSC, 2014, p. 28).

During Lula's years, expressions as "structuring cooperation," "active and proud foreign policy," were quite common in debates on the BFP in health. Health gradually became an important BFP topic, though Lula's era was not exempt of criticism, especially because at times there is a "distance between the grandiloquence of intentions and the materialization of the act" (Buss and Ferreira apud Ventura, 2013, p. 106).

The downfall of Brazil's international insertion, as identified by Cervo and Lessa (2014) and discussed in this article, had an impact on Brazilian strategies in global health. Problems in the administration of international projects already existed during Lula's years, and there was a debate back then requiring a better understanding of those actors involved in the international health cooperation - to avoid problems as the ones that happened with the SMM project in Mozambique -, 
and for better coordination among all different agencies and organisms that took part in this process. Nonetheless, there was a personal commitment from former President Lula to deal with these management problems, and the same could not be verified in Dilma's first term, in which financial restrictions and budgetary cuts, as happened to ABC in Angola, had an even stronger negative impact in some projects. The MOFA and Fiocruz struggled as well with some changes.

The absence of new expressions and concepts in the BFP could be an indicator that Lula's strategies have continued under Dilma's administration. However, the lack of resources and the absence of Dilma's efforts to prioritize BFP and establish new international priorities suggest the opposite situation. For instance, the project with Mozambique waned under Dilma, while evidence show that Unasur, BRICS and CPLP actions in the health field continued due to the effort of individual actors and bureaucratic inertia,

192 instead of proactive efforts from Dilma's administration. In most of these cases, there has been a sluggish continuity in BFP, while Dilma has not made an effort to make projects work better or to speed up the processes.

\section{Eduardo Gómez}

is senior lecturer in international development at King's College London International Development Institute.

\section{Fernanda Aguilar Perez}

is a joint PhD candidate from University of São Paulo/ King's College London, with a Fapesp/Capes scholarship, from São Paulo Research Foundation.

\section{References}

ABDENUR, A. E. et al. 2014. Brazilian health and agricultural cooperation in Mozambique: an overview. BPC Papers, v. 2, n. 5, pp. 1-28. AMORIM, C. 2013. Breves narrativas diplomáticas. São Paulo: Benvirá. 
BADIN, M. R.; FRANÇA, C. 2010. A inserção internacional do Poder Executivo federal brasileiro. Análises e Propostas, São Paulo, n. 40, pp. 1-34. BCA - Brazilian Cooperation Agency. 2015. Projeto PROFORSA. Available at: <http://www.abc.gov.br/imprensa/mostrarnoticia/534>. Accessed on: June 10, 2015.

BLISS, K. 2011. Health diplomacy of foreign governments. Washington, DC: Center for Strategic and International Studies.

BRASIL. 2013. National Budget 2013. Available at: <http://www. orcamentofederal.gov.br/orcamentos-anuais/orcamento-2013-1/loa/ VolumeIV.pdf>. Accessed on: June 1, 2015.

Câmara dos Deputados [The Chamber of Deputies]. 2015a. Atividade legislativa, orçamento e LOA. Vol. IV.

Câmara dos Deputados [The Chamber of Deputies]. 2015b. Aprova o texto do Acordo de Sede entre a República Federativa do Brasil e a União de Nações Sul-Americanas (Unasul) para o funcionamento do Instituto Sul-Americano de Governo em Saúde (ISAGS). Item 21: PDC 24/2015.

BRASIL; MOÇAMBIQUE. 2011. Ajuste complementar ao acordo geral de cooperação entre o Governo da República Federativa do Brasil e o Governo da República de Moçambique para o projeto de instalação da fábrica de antirretrovirais e outros medicamentos em Moçambique. Maputo, Moçambique.

BRICS. 2014. IV Meeting of the Ministers of Health of the BRICS: Joint Communiqué. Available at: <http:/ /u.saude.gov.br/images/pdf/2014/ dezembro/17/Joint-Communiqu-FINAL-ENGLISH-05.12.14.pdf>. Accessed on: June 9, 2015.

BRICS Policy Center. 2014. This week in BRICS, v. 2, n. 65.

BUSS, P.; FERREIRA, J. R. 2011. Cooperação e integração regional em saúde na América do Sul: a contribuição da Unasul-Saúde. Ciência Ẽ Saúde Coletiva, v. 16, n. 6, pp. 2699-711.

CERVO, A. L. 2010. Brazil's rise on the international scene: Brazil and the world. Revista Brasileira de Política Internacional, v. 53, Special Edition, pp. 7-32.

CERVO, A. L.; LESSA, A. C. 2014. O declínio: inserção internacional do Brasil (2011-2014). Revista Brasileira de Politica Internacional, v. 57, n. 2, pp. 133-51.

CHADE, J. 2013. Brasil vai dobrar contribuição para a OMS em 2014. $O$ Estado de S. Paulo. Available at: <http://www.estadao.com.br/noticias/ vidae,brasil-vai-dobrar-contribuicao-para-a-oms-em-2014,1034996,0. htm>. Accessed on: October 17, 2013. 
CHAN, L.; CHEN, L.; XU, J. 2010. China's engagement with global health diplomacy: was SARS a watershed? PLOS Medicine, v. 7, n. 4, e1000266.

COWLEY, M. 2014. Cuba to raise pay of doctors working in Brazil. The Wall Street Journal. Available at: <http:/ / www.wsj.com/articles/SB1000 1424052702304709904579411591801968068>. Accessed on: October $10,2015$.

CPLP - Comunidade dos Países de Língua Portuguesa. 2013. Reunião técnica de avaliação do PECS - 2009-2012. Available at: <http:/ /www. cplp.org/Files/Billeder/cSaude/Relatrio-Aval-PECS-2009-2012_FINAL. pdf $>$. Accessed on: June 09, 2015.

FELDMAN, H.; MICHAUD, J. 2010. Health diplomacy and the enduring relevance of foreign policy interests. PLOS Medicine, v. 7, n. 4, e1000226.

FIGUEIREDO, A. C.; LIMONGI, F. 2000. Presidential power, legislative organization, and party behavior in Brazil. Comparative Politics, v. 32, n. 2, pp. 151-70.

FIOCRUZ - Fundação Oswaldo Cruz. 2013a. CRIS INFORMA \#4. Rio de Janeiro: Fiocruz. Available at: <https://portal.fiocruz.br/sites/portal. fiocruz.br/files/documentos/Cris\%20Informa\%204_0.pdf >. Accessed on: March 15, 2016.

2013b. CRIS INFORMA \#5. Rio de Janeiro: Fiocruz. Available at: $<$ https://portal.fiocruz.br/sites/portal.fiocruz.br/files/documentos/ Cris\%20Informa\%205\%20-\%20JAN-FEV2013_0.pdf>. Accessed on: March 15, 2016.

2013c. CRIS INFORMA \#10. Rio de Janeiro: Fiocruz. Available at: <https://portal.fiocruz.br/sites/portal.fiocruz.br/files/documentos/ Cris\%20Informa\%2010.pdf>. Accessed on: March 15, 2016. 2013d. Relatório de gestão do exercício de 2012. Rio de Janeiro: Fiocruz.

2014. CRIS INFORMA \#12. Rio de Janeiro. Available at: <https:/ / portal.fiocruz.br/sites/portal.fiocruz.br/files/documentos/cris_ informa_12_final_2.pdf>. Accessed on: March 15, 2016. 2015. Relatório de gestão do exercício de 2013. Rio de Janeiro.

FONSECA, J. M.; ESTEVES, P.; GOMES, G. Z. 2015. Brazilian health and agricultural cooperation in Angola: an overview. BPC Papers, v. 3, n. 2, pp. 1-38.

GÓMEZ, E. J. 2012. Understanding Brazilian global health diplomacy: social health movements, institutional infiltration, and the geopolitics of accessing information. Global Health Governance, v. 6, n. 1, pp. 1-29. HERMANN, B. 2011. Soberania, não intervenção e não indiferença: reflexões sobre o discurso diplomático brasileiro. Brasília: Funag. 
HIRST, M. 2012. Aspectos conceituais e práticos da atuação do Brasil em Cooperação Sul-Sul: os casos de Haiti, Bolívia e Guiné Bissau. Rio de Janeiro/Brasília: Ipea (Texto para Discussão, n.1.687).

HUANG, Y. 2010. Pursuing health as a foreign policy: the case of China. Indiana Journal of Global Legal Studies, v. 17, n. 1, pp. 105-46.

2011. Domestic factor's in China's health aid programs in Africa. In: FREEMAN, C. (ed.). China's emerging global health and foreign aid engagement in Africa. Washington, DC: Center for Strategic and International Studies.

HUDSON, V. M. 2014. Foreign policy analysis. Maryland: Rowman \& Littlefield.

ISAGS - Instituto Sul-Americano de Governo em Saúde. 2012. ISAGS Report. Available at: <http://www.isags-unasur.org/uploads/eventos/ ev[47]ling[3] anx[46].pdf>. Accessed on: June 7, 2016. . 2015a. Informe ISAGS. Rio de Janeiro. Available at: <http://www. isags-unasur.org/uploads/eventos/ev[3037]ling[1] anx[497].pdf >. Accessed on: June 8, 2015. 2015b. Informe anual 2014. Available at: <http:/ /www.isagsunasur.org/uploads/biblioteca/7/bb[317]ling[1]anx[1064].pdf>. Accessed on: June 8, 2015.

KICKBUSCH, I. et al. 2013. Global health diplomacy: concepts, issues, actors, instruments, fora, and cases. New York: Springer Press.

LABONTE, R.; GAGNON, M. 2010. Framing health and foreign policy: lessons for global health diplomacy. Globalization $\mathcal{E}^{2}$ Health, v. 6, n. 14, pp. 1-19.

LAFER, C. 2000. Brasil: dilemas e desafios da política externa. Estudos Avançados, v. 14, n. 38, pp. 260-67.

LEE, K.; GÓMEZ, E. J. 2011. Brazil's ascendance: the soft power role of global health diplomacy. European Business Review, pp. 61-64. Available at: <https://www.aber.ac.uk/en/media/departmental/interpol/chair/ KL-Brazil's-ascendance-article.pdf>. Accessed on: February 15, 2016.

LEE, K.; SMITH, R. 2011. What "is" global health diplomacy: a conceptual review. Global Health Governance, v. 5, n. 1, pp. 1-12.

LEITE, P. S. 2011. O Brasil e a operação Sul-Sul em três momentos: os governos Jânio Quadros/João Goulart, Ernesto Geizel e Luiz Inácio Lula da Silva. Brasília: Funag.

MAINWARING, S. 1997. Multipartism, robust federalism and presidentialism in Brazil. In: MAINWARING, S.; SHUGART, M. S. (eds.). Presidentialism and democracy in Latin America. Cambridge: Cambridge University Press. 
MICHAUD, J.; KATES, J. 2012. Raising the profile of diplomacy in the U.S. global health response: a backgrounder on global health diplomacy. Washington, DC: Kaiser Family Foundation. 2013. Global health diplomacy: advancing foreign policy and global health interests. Global Health: Science and Practice, v. 1, n. 1, pp. 24-8.

MILANI, C.; LOPES, R. 2014. Cooperação Sul-Sul e policy transfer em saúde pública: análise das relações entre Brasil e Moçambique entre 2003 e 2012. Carta Internacional, v. 9, n. 1, pp. 59-78.

MOFA - Ministry of Foreign Affairs. 2011. Relatório de visitas internacionais do Presidente Luiz Inácio Lula da Silva e de visitas ao Brasil de Chefes de Estado e de Chefes de Governo entre janeiro de 2003 e dezembro de 2010. Brasília, DF. 2012. Visita a Moçambique do Vice-Presidente da República, Michel Temer e do Ministro das Relações Exteriores, Antonio de Aguiar Patriota - 18 a 20 de julho de 2012. Brasília, DF.

MOFA and MOH - Ministry of Foreign Affairs and Ministry of Health. 2014. Nota à imprensa conjunta dos Ministérios das Relações Exteriores e da Saúde - contribuição brasileira ao combate internacional ao vírus do Ebola. Brasília, DF.

NYE, J. 2004. Soft power: the means to success in world politics. New York: Public Affairs Press.

NOVOTNY, T.; KICKBUSCH, I.; TOLD, M. (eds.). 2013. 21st century global health diplomacy. Singapore: World Scientific Press.

PAHO - PAN AMERICAN HEALTH ORGANIZATION. 2014. Relatório de gestão dos termos de cooperação primeiro semestre de 2014. Brasília, DF. Available at: <http://www.paho.org/bra/images/stories/ Documentos2/rel_de_gestao_1_sem_2014.pdf $>$. Accessed on: June $10,2015$.

PINHEIRO, L.; MILANI, C. 2012. Introdução. In: . Política externa brasileira - as práticas da política e a política das práticas. Rio de Janeiro: FGV. PRESIDENTIAL OFFICE. 2011. Nota oficial-MRE divulga nota informativa sobre a visita da presidenta Dilma Rousseff a Maputo - Moçambique. Brasília, DF. RUSSO, G. et al. 2014. On the margins of aid orthodoxy: the BrazilMozambique collaboration to produce essential medicines in Africa. Globalization and Health, v. 10, n. 70.

SENADO FEDERAL [Federal Senate]. 2003-2014. Brazilian federal budget. All years available at: <http:/ /www12.senado.gov.br/orcamento/ documentos/loa>. Accessed on: March 17, 2016. 2015. Detalhamento das ações de órgãos do poder executivo: 35000 Ministério das Relações Exteriores. Brasília, DF. 
TAYLOR, I. 2015. China's response to the Ebola virus disease in West Africa. The Round Table: The Commonwealth Journal of International Affairs, v. 104, n. 1, pp. 41-54.

TEMPORÃO, J. G. 2014. [José Gomes Temporão:] Interview to Deisy de Freitas Lima Ventura. Rio de Janeiro.

THOMPSON, D. 2005. China's soft power in Africa: from the "Beijing consensus" to health diplomacy. China Brief: A Journal of Analysis and Information, v. 5, n. 21.

TWIGG, J. 2012. Russia's emerging global health leadership. Washington, D.C.: Center for Strategic and International Studies.

UNSC - United Nations Security Council. 2014. Agenda peace and security in Africa. 7268th meeting. Thursday, 18 September 2014. New York S/ PV.7268.

VENTURA, D. 2013. Saúde pública e política externa brasileira. SUR Revista Internacional de Direitos Humanos, v. 10, n. 19, pp. 99-117.

VENTURA, D.; PEREZ, F. A. 2015. A política externa de saúde de Dilma Rousseff (2011-2014): elementos preliminares para um balanço. $5^{\circ}$ Encontro Nacional da ABRI, Belo Horizonte, 29-31 July.

VIGEVANI, T.; CEPALUNI, G. 2007. A política externa de Lula da Silva: a estratégia da autonomia pela diversificação. Contexto Internacional, v. 29, n. 2, pp. 273-335.

WATT, N.; GÓMEZ, E. J.; McKEE, M. 2013. Global health in foreign policy - and foreign policy in health? Evidence from the BRICS. Health Policy Ẽ Planning, v. 29, n. 6, pp. 763-73.

WERLAU, M. 2013. Cuba's healthcare diplomacy: the business of humanitarianism. World Affairs. Available at: <http:/ /www. worldaffairsjournal.org/article/cuba's-health-care-diplomacy-businesshumanitarianism>. Accessed on: February 20, 2016. 


\section{BRAZILIAN FOREIGN POLICY IN HEALTH DURING DILMA ROUSSEFF'S ADMINISTRATION (2011-2014)}

\section{EDUARDO GÓMEZ}

\section{FERNANDA AGUILAR PEREZ}

Abstract: This article analyses changes and continuities in Brazilian international actions in the field of public health, aiming at understanding how the Brazilian foreign policy in health during President Dilma Rousseff's first term (2011-2014) was developed. Available data from President Luiz Inácio Lula da Silva (2003-2010) years and Dilma's first term were used for comparative purposes. Emphasis was given on South-South cooperation projects, more specifically the Union of South American Countries (USAN, Unión de Naciones Suramericanas - Unasur) and to the Community of Portuguese-speaking Countries (CPLP). Brazilian behavior in international fora, such as the World Health Organization, was analyzed as well, with the purpose of understanding how such behavior evolved. In addition, domestic issues were considered. In this case, the coordination among different actors of the Brazilian Executive Power received due attention. Findings suggest that there has been downfall and even decline in the Government's foreign health policy.

Keywords: Foreign Policy; Global Health; Cooperation.

\section{A POLÍTICA EXTERNA BRASILEIRA EM SAÚDE DURANTE 0 GOVERNO DE DILIMA ROUSSEFF (2011-2014)}

Resumo: Este artigo analisa mudanças e continuidades nas ações internacionais do Brasil no campo da saúde pública, buscando compreender o desenvolvimento da política externa brasileira em saúde durante o primeiro mandato da Presidente Dilma Rousseff (2011-2014). Dados relativos à presidência de Luiz Inácio Lula da Silva (2003-2010) e do primeiro mandato de Dilma foram usados para fins de comparação. Projetos da 
Cooperação Sul-Sul receberam ênfase, mais especificamente os da União das Nações Sul-Americanas (Unasul, Unión de Naciones Suramericanas - Unasur) e da Comunidade dos Países de Língua Portuguesa (CPLP). O comportamento do Brasil em órgãos internacionais, como a Organização Mundial de Saúde (OMS), também foi analisado, com o propósito de compreender como tal comportamento evoluiu. Além disso, foram considerados os problemas internos. Neste caso, a coordenação entre diferentes atores do Poder Executivo brasileiro recebeu a devida atenção. Os resultados sugerem que houve uma retração ou até mesmo um declínio da política externa em saúde do país.

Palavras-chave: Política Externa; Saúde Global; Cooperação.

Recebido em: 29/3/2016 Aprovado em: 17/6/2016 